\title{
Salt-tolerant chitin and chitosan modifying enzymes from Talaromyces stipitatus, a mangrove endophyte
}

\section{Paranetharan $\mathrm{MS}^{1,2}$, Thirunavukkarasu $\mathrm{N}^{1}$, Rajamani $\mathrm{T}^{1,2}$, Murali $\mathrm{TS}^{3}$ and Suryanarayanan $\mathbf{T S}^{2, *}$}

\author{
${ }^{1} P G$ \& Research Department of Botany, Ramakrishna Mission Vivekananda College, Chennai 600004. \\ ${ }^{2}$ Vivekananda Institute of Tropical Mycology, Ramakrishna Mission Vidyapith, Chennai 600004. \\ ${ }^{3}$ Division of Biotechnology, School of Life Sciences, Manipal Academy of Higher Education, Manipal, Karnataka \\ 576104.
}

Paranetharan MS, Thirunavukkarasu N, Rajamani T, Murali TS, Suryanarayanan TS 2018 - Salttolerant chitin and chitosan modifying enzymes from Talaromyces stipitatus, a mangrove endophyte. Mycosphere 9(2), 215-226, Doi 10.5943/mycosphere/9/2/5

\begin{abstract}
In this paper, we show that a Talaromyces stipitatus isolated as an endophyte from the root of the mangrove tree Avicennia marina, produces salt-tolerant chitinase and chitosanases. The endophyte is halotolerant and produces these chitin modifying enzymes even in the presence of a high concentration of $\mathrm{NaCl}$ in the growth medium. The chitosanases produced could act on chitosans of low, medium and high degrees of acetylation. The presence of $\mathrm{NaCl}$ influenced the production of isoforms of chitinase and chitosanase by the endophyte. The chitinase activity was not altered much by $\mathrm{NaCl}$ concentration.
\end{abstract}

Key words - chitinase - chitosanase - halotolerant enzymes - fungal enzymes

\section{Introduction}

Chitin is made of repeating units of $\beta-1,4$ linked $N$-acetyl-D-glucosamine and is an essential part of fungal cell walls, shell of crustaceans and exoskeleton of insects. Fungi produce nearly 25 different chitinases (Seidl 2008) to facilitate restructuring of their cell walls during growth, branching, fusion of hyphae and also to aid in parasitism (Adams 2004). Fungal chitinases belong to glycosyl hydrolase $(\mathrm{GH}) 18$ family. Fungi also produce chitin deacetylases which deacetylate chitin to chitosans, which are further degraded by chitosanases. Chitin and its derivatives have many industrial and pharmaceutical uses (Howard et al. 2003). They could be used for biological control of parasites, drug delivery, wound healing, and waste water treatment (Dahiya et al. 2006, Aoyagi et al. 2007, Nam et al. 2010). Likewise, chitooligosaccharides have many pharmaceutical applications including in tumour and asthma inhibition, in treatment of osteoporosis and wounds, as antibacterial, anti fungal and anti malarial agents and as vectors for gene delivery (Aam et al. 2010). Purification and modification of chitin using chemical methods are difficult and hence, chitin-modifying enzymes of microbial source are explored for these activities (Muzzarelli 1999). In this regard, chitin modifying enzymes from fungi have attracted much attention (Gortari \& Hours 2008).

In the recent times, fungi from little-explored habitats such as endophytes of terrestrial plants (Govinda Rajulu et al. 2011, Cord-Landwehr et al. 2016), marine algae and seagrasses 
(Venkatachalam et al. 2015), fungi from soils exposed to chitin products (Malathi et al. 2015) and thermophilic fungi ( $\mathrm{Li}$ et al. 2010) have been explored with the aim of finding novel chitin modifying enzymes. Considering the roles of chitin modifying enzymes in generating products of biotechnological potential, it is essential that several fungi from unique habitats are studied for elucidation of these enzymes. It is also of much importance to study them in detail since several aspects of these enzymes including their regulation and specific roles are not yet clearly understood (Seidl 2008, Govinda Rajulu et al. 2011).

In the present study, we screened an endophytic fungus isolated from the root of a mangrove tree for its chitinase and chitosanase activities. Endophytes are mostly ascomycete fungi which are non-disease causing endosymbionts of plants (Hyde \& Soytong 2008).

\section{Materials \& Methods}

\section{Fungal source}

In an initial study, we screened for chitinase several endophytes from Vivekananda Institute of Tropical Mycology (VINSTROM)'s culture collection and those we isolated from the roots of mangroves of Pichavaram $\left(11.4226^{\circ} \mathrm{N}, 79.7748^{\circ} \mathrm{E}\right)$, Tamilnadu state. An endophyte isolated from the root of the mangrove Avicennia marina showed the maximum chitinase activity and was selected for further study. Based on culture and molecular characteristics (explained in the next sections), it was identified as Talaromyces stipitatus (Thom) Benjamin (三 Penicillium stipitatum Thom) and was screened for the production of salt-tolerant chitinase and chitosanases.

\section{Test for salt-tolerance}

The fungus was grown on Czapek Dox Agar medium (CDA) for 5 days and the margin of the colony was cut with a sterile cork borer $(5 \mathrm{~mm}$ dia) and this mycelial plug was placed (mycelial surface down) at the center of a Petri dish $(9 \mathrm{~cm} \mathrm{dia.)} \mathrm{containing} 20 \mathrm{ml}$ of CDA amended with different concentrations of $\mathrm{NaCl}(0,1.5 \%, 2.5 \%, 3.5 \%$, or $4.5 \%)$ (Cantrell et al. 2006). Petri dishes were incubated at $26 \pm 2^{\circ} \mathrm{C}$ and the colony diameter was measured every day with calipers. Replicates were maintained for each treatment.

\section{Preparation of samples for detecting chitinase and chitosanases}

The endophyte was grown in Potato Dextrose medium [potato $200 \mathrm{~g}$, dextrose $20 \mathrm{~g}$, distilled water 11, pH 6.0 with different concentration of $\mathrm{NaCl}(0,1.5 \%, 2.5 \%, 3.5 \%$, or $4.5 \%)]$ for 5 days as static culture at $26 \pm 2^{\circ} \mathrm{C}$. The mycelium was filtered and $100 \mathrm{ml}$ of the culture filtrate was dialyzed for $15 \mathrm{~h}$ against distilled water. The dialyzed culture filtrate was lyophilized and used as crude enzyme source for detecting chitin modifying enzymes.

\section{Spectrophotometric assay for chitinase (Govindarajulu et al. 2011)}

A reaction mixture made of $0.6 \mathrm{ml}$ of $0.1 \mathrm{M}$ sodium acetate buffer ( $\mathrm{pH} 5.2), 0.2 \mathrm{ml}$ of CMchitin-RBV (Remazol brilliant violet-dye labeled chitin, Löwe Biochemica, Germany), and $0.02 \mathrm{ml}$ of enzyme preparation ( $5 \mathrm{mg}$ of freeze dried powder mixed in buffer) was prepared. The blank tube contained all the reagents except the enzyme which was replaced with $0.02 \mathrm{ml}$ of buffer. The reaction mixture was incubated at $37^{\circ} \mathrm{C}$ for $60 \mathrm{~min}$ allowing the substrate to be digested. The reaction was terminated by adding $0.2 \mathrm{ml}$ of $2 \mathrm{~N} \mathrm{HCl}$, incubated at $0^{\circ} \mathrm{C}$ for $10 \mathrm{~min}$, and centrifuged at high speed for $5 \mathrm{~min}$. The supernatant was assayed for enzyme activity by measuring the absorbance at $550 \mathrm{~nm}$ (Wirth \& Wolf 1990, Govindarajulu et al. 2011). The enzyme activity is expressed as $\Delta \mathrm{A} 550 \mathrm{~nm} / \mathrm{h} \times \mathrm{mg} \times$ protein.

\section{Dot blot assay for chitinase and chitosanases (Govindarajulu et al. 2011)}

A composite gel consisting of stacks of glycol chitin or chitosans of 1.6, 38 or $56 \%$ degree of acetylation (DA) was layered as follows. A gel was prepared by mixing a solution of $1 \mathrm{ml}$ of $30 \%$ Acrylamide/Bisacrylamide, $0.3 \mathrm{ml}$ substrate (glycol chitin or one of the chitosans), $1.7 \mathrm{ml}$ of 
Sodium acetate buffer ( $\mathrm{pH} 5.2$ ), $0.003 \mathrm{ml}$ of $40 \%$ Ammonium persulphate and $0.003 \mathrm{ml}$ of $100 \%$ TEMED. The surface of this gel was layered with butanol to aid polymerization. Accordingly, a compound gel consisting of glycol chitin or chitosan (of 56,38 or $1.6 \%$ DA) was obtained.

$10 \mathrm{mg}$ of the lyophilized culture filtrate of the fungus (grown in different $\mathrm{NaCl}$ concentrations as mentioned above) was mixed with $1 \mathrm{ml}$ of $50 \mathrm{mM}$ sodium acetate buffer (pH 5.2) and centrifuged at high speed for $5 \mathrm{~min} ; 5 \mu \mathrm{l}$ of the supernatant was spotted on the gel and incubated at $37^{\circ} \mathrm{C}$ for $12 \mathrm{~h}$. The gels were stained with $0.01 \%$ calcofluor white for $5 \mathrm{~min}$, washed with distilled water for $1 \mathrm{~h}$ and observed under UV transilluminator to detect zones of darkness which indicated enzyme activity.

\section{Zymography for chitinase and chitosanases (Govindarajulu et al. 2011)}

A separating gel containing $4 \mathrm{ml}$ of $30 \%$ Acrylamide/Bisacrylamide, $1 \mathrm{ml}$ of substrate [1\% glycol chitin or $0.1 \%$ chitosans of $1.6,38$ or $56 \%$ (DA)], $2.5 \mathrm{ml}$ of $1.5 \mathrm{M}$ Tris $\mathrm{HCl}$ buffer $(\mathrm{pH} 8.8$ ), $2.5 \mathrm{ml}$ of deionized water, $0.010 \mathrm{ml}$ of $40 \%$ ammonium persulphate and $0.010 \mathrm{ml}$ of $100 \%$ TEMED was prepared, poured into a gel cassette and left for $20 \mathrm{~min}$ for polymerization. After polymerization, the stacking gel was prepared by mixing $0.85 \mathrm{ml}$ of $30 \%$ Acrylamide/Bisacrylamide, $1.25 \mathrm{ml}$ of $0.5 \mathrm{M}$ Tris $\mathrm{HCl}$ buffer $(\mathrm{pH} 6.8), 2.9 \mathrm{ml}$ of deionized water, $0.005 \mathrm{ml}$ of $40 \%$ Ammonium persulphate and $0.005 \mathrm{ml}$ of $100 \%$ TEMED and layered on the separating gel in the cassette. A comb was inserted between the gel cassettes.

The sample was prepared as mentioned under the dot blot assay. The supernatant $(25 \mu \mathrm{l})$ was mixed with $25 \mu \mathrm{l}$ of sample buffer without $\beta$-mercaptoethanol and subjected to SDS-PAGE. After electrophoresis (50 mA for $5 \mathrm{~h}$ ), the gel was washed twice for $20 \mathrm{~min}$ in $50 \mathrm{mM} \mathrm{Na}$-acetate buffer (pH 5.2) with $1 \%$ Triton X-100. It was then washed twice in the same buffer (without $1 \%$ Triton $\mathrm{X}-100$ ) for $20 \mathrm{~min}$ to remove the Triton $\mathrm{X}-100$. The gel was incubated at $37^{\circ} \mathrm{C}$ for $12 \mathrm{~h}$ under shaking in $50 \mathrm{mM} \mathrm{Na}$-acetate buffer ( $\mathrm{pH}$ 5.2) solution, and then stained with $0.01 \%$ calcofluor in $0.5 \mathrm{M}$ Tris-buffer ( $\mathrm{pH}$ 8.9) solution for $5 \mathrm{~min}$; finally, the gel was washed with deionized water for $1 \mathrm{~h}$ and visualized under UV transilluminator.

\section{Genomic DNA extraction}

The mycelium from a 6-day old PDA grown culture was treated with $500 \mu \mathrm{l}$ of DNA extraction Lysis buffer (1M Tris, 5M NaCl, 0.5M EDTA, $10 \%$ SDS) for overnight at room temperature. After incubation, equal volume of phenol was added, mixed briefly and centrifuged at $10600 \mathrm{~g}$ for $15 \mathrm{~min}$ at $4^{\circ} \mathrm{C}$ (Eppendorf 5810R). The upper clear layer was transferred to a fresh tube and to this, equal volumes of chloroform: isoamylalcohol (24:1) was added and centrifuged at $10600 \mathrm{~g}$ for $15 \mathrm{~min}$ at $4^{\circ} \mathrm{C}$. The upper layer was then precipitated using $0.3 \mathrm{M}$ Sodium acetate and absolute alcohol by incubating for $3 \mathrm{~h}$ at $-80^{\circ} \mathrm{C}$. The tubes were then thawed and centrifuged at $10600 \mathrm{~g}$ for $15 \mathrm{~min}$ at $4^{\circ} \mathrm{C}$. The supernatant was discarded and $100 \mu \mathrm{TE}$-Buffer and $15 \mu \mathrm{l}$ of RNase $(10 \mathrm{mg} / \mathrm{ml})$ were added and the tubes were incubated for $45 \mathrm{~min}$ at $37^{\circ} \mathrm{C}$. The genomic DNA was again precipitated by adding 0.7 volume of isopropanol and 0.1 volume $0.3 \mathrm{M}$ Sodium acetate and centrifuged at $10600 \mathrm{~g}$ for $15 \mathrm{~min}$ at $4{ }^{\circ} \mathrm{C}$. The pellet was washed with $70 \%$ ethanol and the genomic DNA obtained was run in a $0.8 \%$ agarose gel.

\section{PCR amplification and sequencing of ITS region}

The amplification of the ITS region was carried out using the primers ITS1 (5'TCCGTAGGTGAACCTGCGG-3') and ITS4 (5'-TCCTCCGCTTA1TTGATATGC-3') (White et al. 1990). PCR was carried out in a $25 \mu \mathrm{L}$ reaction mix consisting of $10 \mathrm{X}$ PCR buffer, forward and reverse primers (10 $\mu \mathrm{M}$ each), $4 \mathrm{mM}$ dNTPs, 1 Unit of Taq DNA Polymerase, $1 \%$ DMSO, 25mM $\mathrm{MgCl}_{2}$ and $\sim 50 \mathrm{ng}$ of fungal genomic DNA as template. The cycling reactions were performed in a Master Cycler Thermocycler (Eppendorf, USA) under the following conditions: $95^{\circ} \mathrm{C}$ for $10 \mathrm{~min}$, followed by 30 cycles of $95^{\circ} \mathrm{C}$ for $60 \mathrm{~s}, 55^{\circ} \mathrm{C}$ for $60 \mathrm{~s}$ and $72^{\circ} \mathrm{C}$ for $90 \mathrm{~s}$, and finally at $72^{\circ} \mathrm{C}$ for 10 min. The amplicons were checked on $1.5 \%$ agarose gel to determine product size and purity. The amplicons were purified using gel elution technique and then sequenced using ABI 3130 Genetic 
Analyzer using both the forward and reverse primers. The sequences were manually edited and aligned using BioEdit software and then searched for similarity using NCBI Blast.

The ITS1-5.8S-ITS2 sequence fragment of Talaromyces sp. was aligned with published sequences from the type specimens of Talaromyces and Penicillium (anamorph) available from GenBank database. The sequences were downloaded and aligned using ClustalW (Thompson et al. 1994) with default settings. In the final analysis a total of 76 nucleotide sequences were included (Table 1). The aligned sequences were then manually adjusted and evolutionary tree of the datasets were inferred using Maximum Likelihood method (Tamura \& Nei 1993) by using MEGA version 6.06 (Tamura et al. 2011) to identify closely related sequences. The branch support was assessed by performing a bootstrap analysis with 1000 replicates (Felsenstein 1985). All ambiguous positions containing gaps and missing data were eliminated and a total of 437 positions were included in the final dataset. A culture of this fungus has been deposited with National Fungal Culture Collection of India, Pune (Accession No. 4222) and the ITS sequence has been deposited in GenBank (Accession No. MG996147).

\section{Results}

The endophyte did not have an obligatory requirement for salt to grow indicating that it is not halophilic. It grew on the highest concentration of $\mathrm{NaCl}$ tested $(4.5 \%=0.8 \mathrm{M})$ proving that it is halotolerant (Fig. 1). A spectrophotometric assay showed that the endophyte produced chitinase in $\mathrm{NaCl}$-amended growth medium as well as in control medium lacking $\mathrm{NaCl}$. The activity of chitinase was slightly more when the fungus was grown on medium having $1.5,2.5$ or $3.5 \%$ of $\mathrm{NaCl}$ than that on control medium (Fig. 2); however, chitinase activity was marginally low in the medium amended with $4.5 \% \mathrm{NaCl}$. A dot blot test also confirmed that the fungus produced chitinase in all the concentrations of $\mathrm{NaCl}$ tested (Fig. 3). This test also revealed that the endophyte produced chitosanases acting on chitosans with high (56\%), medium (38\%) and low (1.6\%) degrees of acetylation (Fig. 3); furthermore, the production of these enzymes was not affected by $\mathrm{NaCl}$ concentration used (Fig. 3). A sensitive polyacrylamide gel electrophoresis for visualizing isoforms of chitinase and chitosanases showed that new isoforms of the enzymes were induced by the presence of $\mathrm{NaCl}$ in the growth medium (Fig. 4).

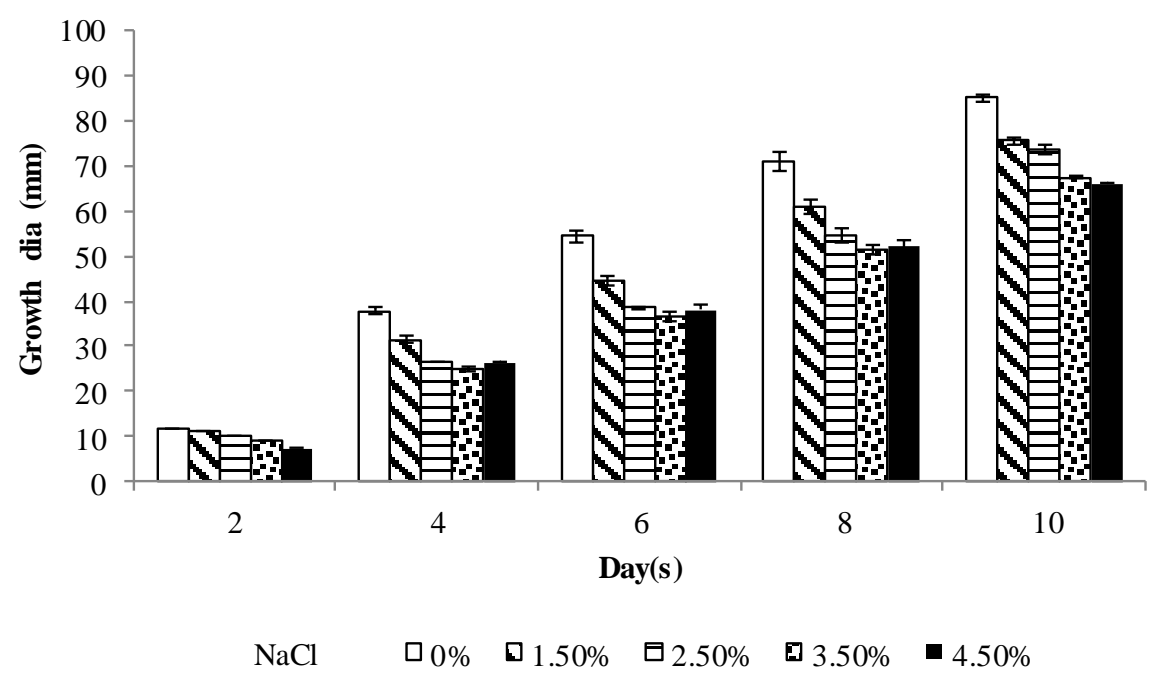

Figure 1 - Growth of $T$. stipitatus in the presence of different concentrations of $\mathrm{NaCl}$ in the growth medium. Bars represent Standard Error. 


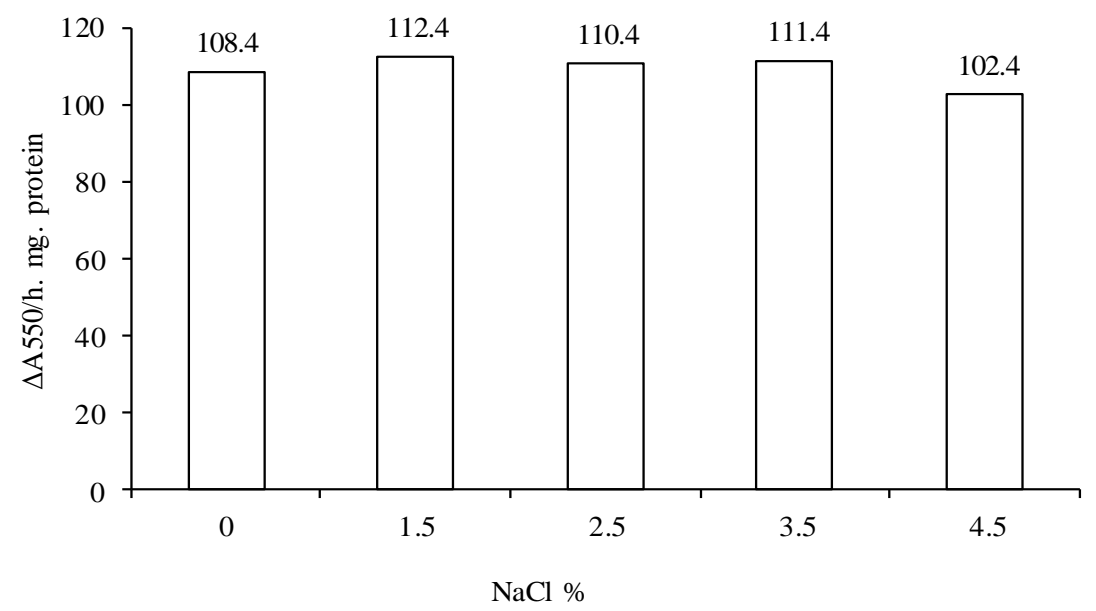

Figure 2 - Chitinase activity of $T$. stipitatus as influenced by different $\mathrm{NaCl}$ concentrations in the growth medium.

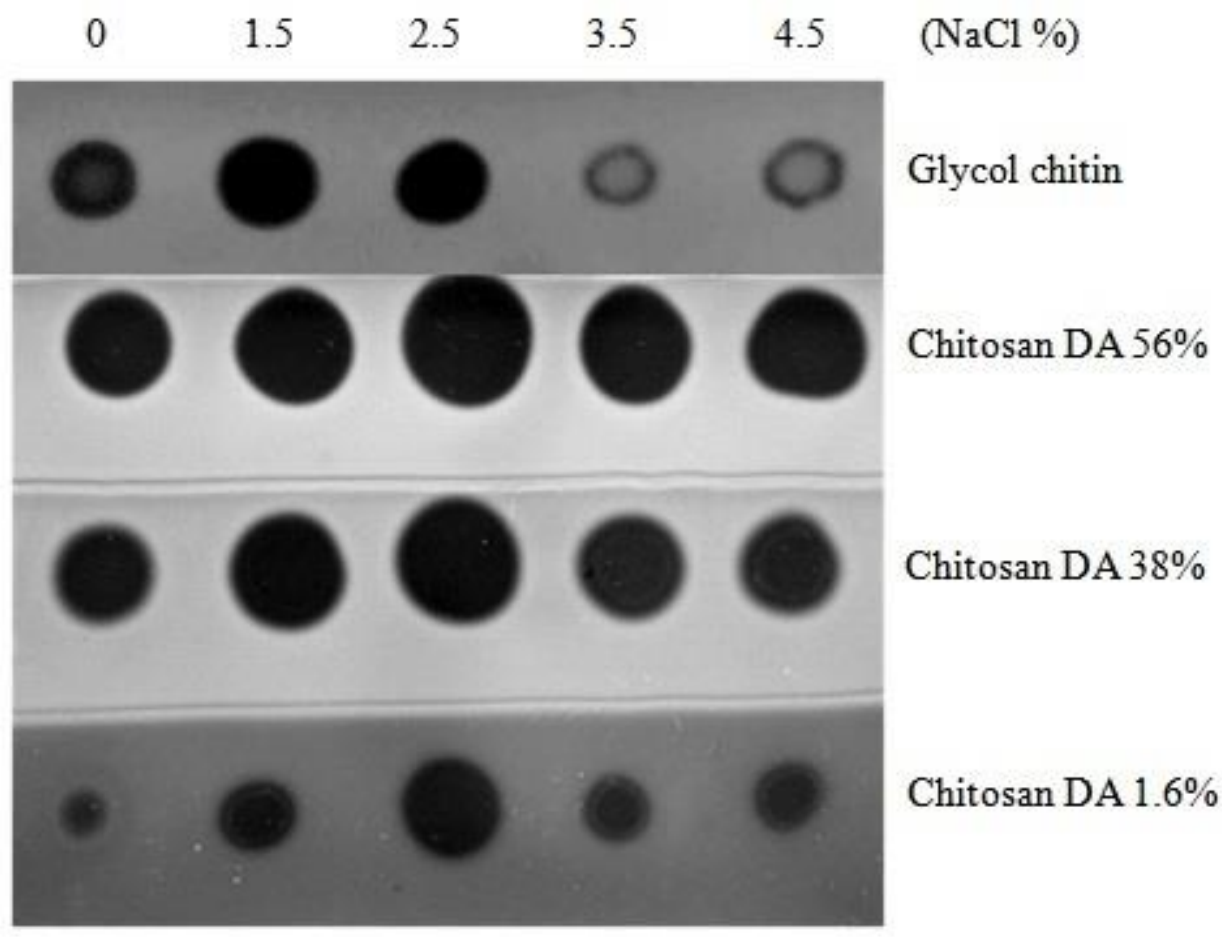

Figure 3 - Dot blot assay for chitinase and chitosanases of T. stipitatus. 


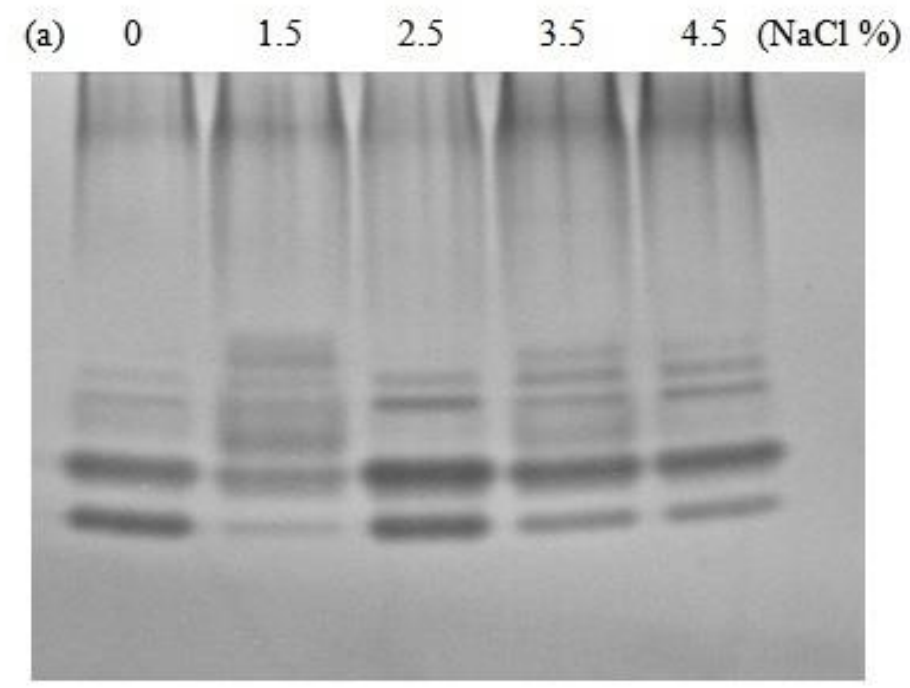

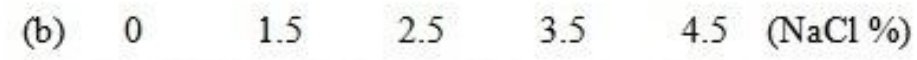

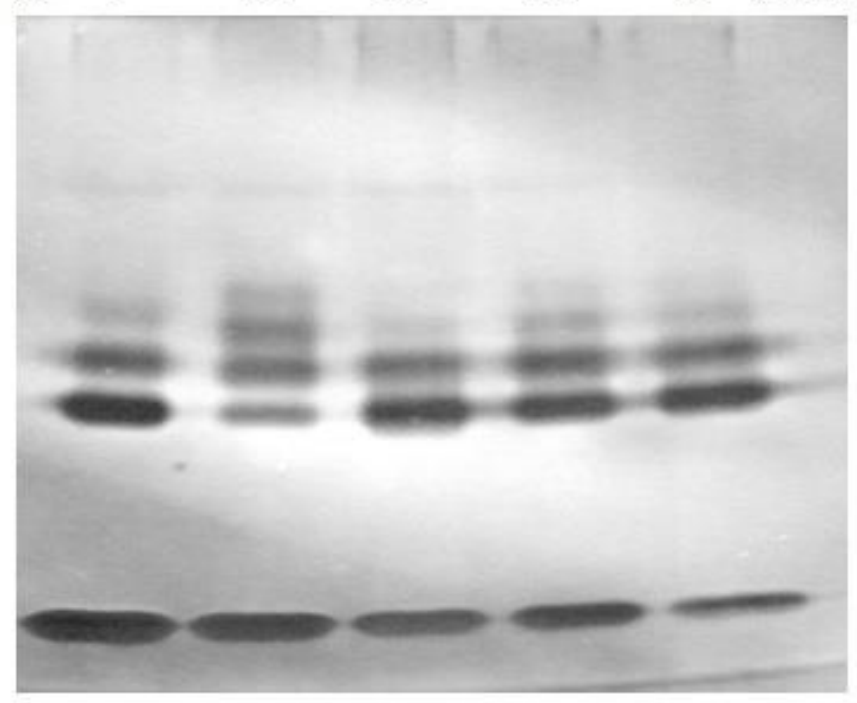

(c) $0 \quad 1.5 \quad 2.5 \quad 3.5 \quad 4.5(\mathrm{NaCl} \%)$

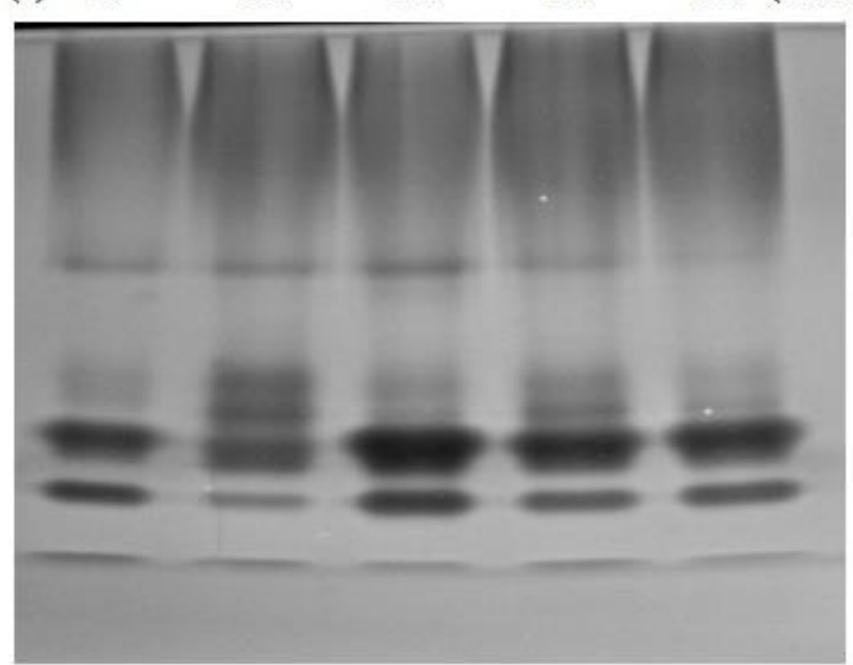

Figure 4 - Isoforms of chitinase (a) and chitosanases (b-Chitosan DA 56\% and c-Chitosan DA $38 \%$ ) of $T$. stipitatus as influenced by different concentrations of $\mathrm{NaCl}$ in the growth medium. 
Table 1 Accession number of isolates used for phylogenetic analysis.

\begin{tabular}{|c|c|c|}
\hline Sl. No. & $\begin{array}{c}\text { Accession } \\
\text { Number }\end{array}$ & Isolate (Type material) \\
\hline 1 & MG996147 & Our isolate \\
\hline 2 & NR103661 & Penicillium adametzii \\
\hline 3 & NR138263 & Penicillium brefeldianum \\
\hline 4 & NR121299 & Penicillium brevicompactum \\
\hline 5 & NR111551 & Penicillium carneum \\
\hline 6 & NR077145 & Penicillium chrysogenum \\
\hline 7 & NR121224 & Penicillium citrinum \\
\hline 8 & NR121317 & Penicillium clavigerum \\
\hline 9 & NR138293 & Penicillium coeruleum \\
\hline 10 & NR121312 & Penicillium coffeae \\
\hline 11 & NR144827 & Penicillium consobrinum \\
\hline 12 & NR138349 & Penicillium fuscum \\
\hline 13 & NR138342 & Penicillium fusisporum \\
\hline 14 & NR103692 & Penicillium griseofulvum \\
\hline 15 & NR137913 & Penicillium hoeksii \\
\hline 16 & NR121311 & Penicillium indicum \\
\hline 17 & NR103693 & Penicillium kewense \\
\hline 18 & NR138336 & Penicillium kongii \\
\hline 19 & NR121222 & Penicillium lividum \\
\hline 20 & NR138339 & Penicillium ludwigii \\
\hline 21 & NR137878 & Penicillium mexicanum \\
\hline 22 & NR137129 & Penicillium monsserratidens \\
\hline 23 & NR138270 & Penicillium montanense \\
\hline 24 & NR121518 & Penicillium nothofagi \\
\hline 25 & NR121232 & Penicillium oxalicum \\
\hline 26 & NR111816 & Penicillium persicinum \\
\hline 27 & NR121258 & Penicillium pimiteouiense \\
\hline 28 & NR121230 & Penicillium raperi \\
\hline 29 & NR121239 & Penicillium restrictum \\
\hline 30 & NR121231 & Penicillium reticulisporum \\
\hline 31 & NR103621 & Penicillium roqueforti \\
\hline 32 & NR111494 & Penicillium roseopurpureum \\
\hline 33 & NR138351 & Penicillium roseoviride \\
\hline 34 & NR111815 & Penicillium rubens \\
\hline 35 & NR121243 & Penicillium rubidurum \\
\hline 36 & NR137849 & Penicillium salmoniflumine \\
\hline 37 & NR077157 & Penicillium sclerotiorum \\
\hline 38 & NR111819 & Penicillium sinaicum \\
\hline 39 & NR077158 & Penicillium spinulosum \\
\hline 40 & NR119812 & Penicillium sumatrense \\
\hline 41 & NR111508 & Penicillium svalbardense \\
\hline 42 & NR111486 & Penicillium tropicoides \\
\hline 43 & NR111485 & Penicillium tropicum \\
\hline 44 & NR138355 & Penicillium trzebinskii \\
\hline 45 & NR153221 & Penicillium tubakianum \\
\hline 46 & NR121251 & Penicillium tularense \\
\hline
\end{tabular}


Table 1 Continued.

\begin{tabular}{|c|c|c|}
\hline Sl. No. & $\begin{array}{c}\text { Accession } \\
\text { Number }\end{array}$ & Isolate (Type material) \\
\hline 47 & NR121257 & Penicillium turbatum \\
\hline 48 & NR137907 & Penicillium vagum \\
\hline 49 & NR119495 & Penicillium verrucosum \\
\hline 50 & NR077137 & Penicillium virgatum \\
\hline 51 & NR121209 & Penicillium viticola \\
\hline 52 & NR111491 & Penicillium waksmanii \\
\hline 53 & NR153225 & Penicillium wisconsinense \\
\hline 54 & NR111501 & Penicillium zonatum \\
\hline 55 & NR120179 & Talaromyces amestolkiae \\
\hline 56 & NR121530 & Talaromyces apiculatus \\
\hline 57 & NR147431 & Talaromyces australis \\
\hline 58 & NR147433 & Talaromyces columbinus \\
\hline 59 & NR103669 & Talaromyces diversus \\
\hline 60 & NR121528 & Talaromyces echinosporus \\
\hline 61 & NR147430 & Talaromyces kendrickii \\
\hline 62 & NR103671 & Talaromyces marneffei \\
\hline 63 & NR103672 & Talaromyces muroii \\
\hline 64 & NR145151 & Talaromyces primulinus \\
\hline 65 & NR121529 & Talaromyces purpureogenus \\
\hline 66 & NR145153 & Talaromyces purpureus \\
\hline 67 & NR147439 & Talaromyces qii \\
\hline 68 & NR111780 & Talaromyces ruber \\
\hline 69 & NR103682 & Talaromyces rubicundus \\
\hline 70 & NR103683 & Talaromyces siamensis \\
\hline 71 & NR147424 & Talaromyces stipitatus \\
\hline 72 & NR111781 & Talaromyces stollii \\
\hline 73 & NR147428 & Talaromyces thailandensis \\
\hline 74 & NR145156 & Talaromyces udagawae \\
\hline 75 & NR153228 & Talaromyces veerkampii \\
\hline 76 & NR103675 & Talaromyces verruculosus \\
\hline
\end{tabular}

The ITS1-5.8S-ITS2 sequence fragment of the endophyte isolate showed a $100 \%$ match with Talaromyces stipitatus HF05001 (Acc. No. KU057945). A Maximum Likelihood analysis was performed to compare our sequence with other related sequences belonging to genera Talaromyces and Penicillium (anamorph state of Talaromyces) available in GenBank database. For this analysis, we included only sequences obtained from type material. A total of 76 sequences (23 sequences belonging to Talaromyces and 53 belonging to Penicillium) were used for this analysis. The maximum likelihood tree showed two well separated clades, one belonging to all Talaromyces isolates and the other consisting of isolates belonging to Penicillium sp. Our sequence formed a tight clade with very high bootstrap support with sequences belonging to T. stipitatus (Fig. 5).

\section{Discussion}

Mangroves are intertidal habitats where wood and other substrates are decayed by salt tolerant fungi (Hyde \& Jones 1998, Hyde \& Lee 1998) and there has been much research on the biodiversity of both saprobes and endophytes in this milieu (Suryanarayanan et al. 1998, Kumaresan \& Suryanarayanan 2001, 2002). In this study we used an endophyte isolate from mangroves to determine the salt-tolerant chitinase and chitosanases, which facilitate life in such 


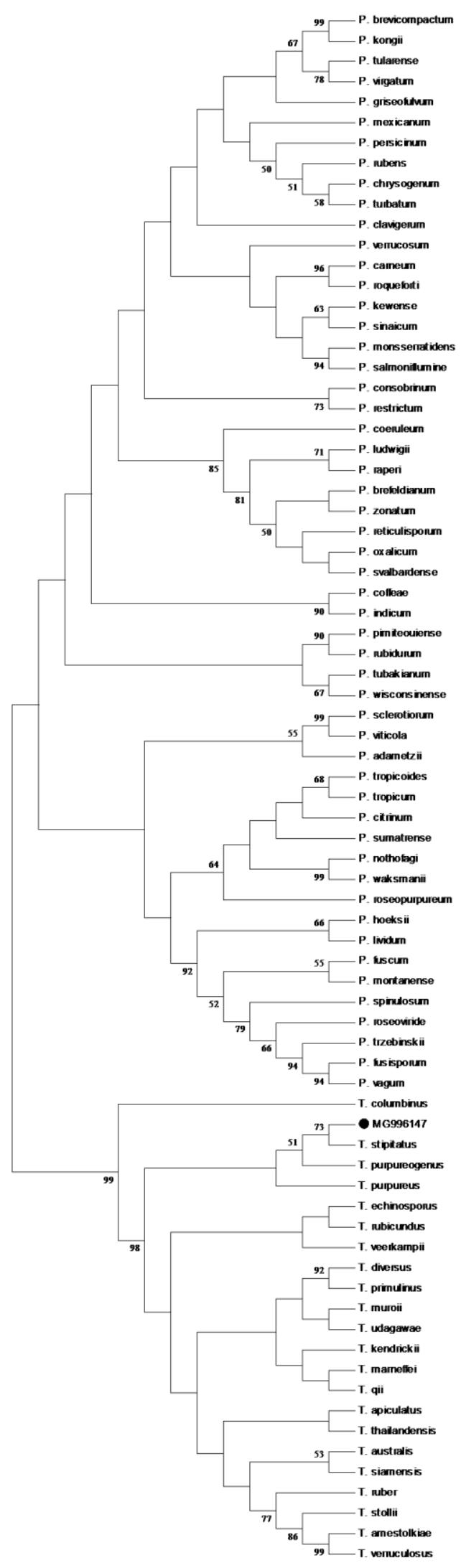

Figure 5 - Bootstrap consensus tree inferred using maximum likelihood method based on the Tamura-Nei model for aligned ITS rDNA sequences of Talaromyces (T) and Penicillium (P) species. Bootstrap values above 50\% from 1000 replications are shown next to the branches. MG996147 is the fungus used in the current study. 
saline environments (Venkatachalam et al. 2015, Thirunavukkarasu et al. 2017). We have limited information regarding chitin and chitosan modifying enzymes of fungi than those of bacteria (Malathi et al. 2015). It would therefore be useful to investigate fungi from different ecological niches for these industrially useful enzymes (Govinda Rajulu et al. 2011). Talaromyces stipitatus is known to produce several novel enzymes (Garcia-Conesa et al. 2004, Mandalari et al. 2008). Here we show that a $T$. stipitatus isolated as an endophyte in the roots of a mangrove produces salt tolerant chitinase and chitosanases and that $\mathrm{NaCl}$ induces the expression of new isoforms of chitinase and chitosanases. Earlier, we have reported that many endophytes isolated from leaves of terrestrial plants (Govinda Rajulu et al. 2011) and endophytes of marine algae and seagrasses (Venkatachalam et al. 2015) produce chitinases; it is interesting to note that the activity of chitinase observed from T. stipitatus (No. 4222) is five to twenty times more than that reported by us for the terrestrial (Govinda Rajulu et al. 2011) or marine plant endophytes (Venkatachalam et al. 2015). This increased activity of chitinase as well as the induction of its isoforms by salt in T. stipitatus warrant further studies. With reference to chitosanase, a strain of T. stipitatus (B8M2R4) has been previously reported to produce a chitosanase belonging to glycosyl hydrolase (GH) family 75 (Zhu et al. 2012). Interestingly, the endophyte in the present study produced salt-tolerant chitosanases which acted on chitosans with very low as well as high degrees of acetylation. The induction of isoforms of chitosanase by $\mathrm{NaCl}$ in this fungus indicates that the influence of salt on chitin modifying enzymes of halotolerant fungi has to be studied in detail. Being a mangrove tree, the roots of Avicennia marina, from where the endophyte was isolated in the present study, are subjected to wide fluctuations in salinity. Since high salt stress increases the levels of chitinases in salt-tolerant plants (Wang et al. 2015), further studies in this direction will provide clues on whether chitinases of endophytes of mangrove roots influence their host metabolism. Moreover, chitin and chitosans are known to stimulate defense responses in plants resulting in the accumulation of pathogenesis related proteins and phytoalexins (El Hadrami et al. 2010). Since endophytes are persistent members of the plant microbiome, it would be worthwhile to address the role of chitin and chitosan modifying enzymes of these endosymbionts in biotic stress tolerance of mangroves as well. Additionally, our results show that root endophytes of mangroves could be explored for novel salt-tolerant chitin modifying enzymes which could be exploited technologically.

\section{Acknowledgements}

TSS thanks the Department of Biotechnology, Government of India, for funding the project (BT/PR7026/NDB/39/458/2013) and Swami Shukadevananda, Chairman, VINSTROM for facilities. We are grateful to Prof. Bruno Moerschbacher, Institute of Plant Biotechnology and Biology, University of Münster for gifting chitin and chitosan.

\section{References}

Aam BB, Heggset EB, Norberg AL, Sørlie M et al. 2010 - Production of chit oligosaccharides and their potential applications in medicine. Marine Drugs 8, 1482-1517.

Adams DJ. 2004 - Fungal cell wall chitinases and glucanases. Microbiology 150, 2029-2035.

Aoyagi S, Onishi H, Machida Y. 2007 - Novel chitosan wound dressing loaded with minocycline for the treatment of severe burn wounds. International Journal of Pharmaceutics 330, 138145.

Cantrell SA, Casillas-Martínez L, Molina M. 2006 - Characterization of fungi from hypersaline environments of solar salterns using morphological and molecular techniques. Mycological Research 110, 962-970.

Cord-Landwehr S, Melcher RL, Kolkenbrock S, Moerschbacher BM. 2016 - A chitin deacetylase from the endophytic fungus Pestalotiopsis sp. efficiently inactivates the elicitor activity of chitin oligomers in rice cells. Scientific Reports 6, 38018. 
Dahiya N, Tewari R, Hoondal GS. 2006 - Biotechnological aspects of chitinolytic enzymes: a review. Applied Microbiology and Biotechnology 71, 773-782.

El Hadrami A, Adam LR, El Hadrami I, Daayf F. 2010 - Chitosan in plant protection. Marine Drugs 8, 968-987.

Felsenstein J. 1985 - Confidence limits on phylogenies: An approach using the bootstrap. Evolution 39, 783-791.

Garcia-Conesa MT, Crepin VF, Goldson AJ, Williamson G et al. 2004 - The feruloyl esterase system of Talaromyces stipitatus: production of three discrete feruloyl esterases, including a novel enzyme, TsFaeC, with a broad substrate specificity. Journal of Biotechnology 108, 227-241.

Gortari MC, Hours RA. 2008 - Fungal chitinases and their biological role in the antagonism on to nematode eggs: a review. Mycological Progress 7, 221-238.

Govinda Rajulu MB, Thirunavukkarasu N, Suryanarayanan TS, Ravishankar JP et al. 2011 Chitinolytic enzymes from endophytic fungi. Fungal Diversity 47, 43-53.

Howard MB, Ekborg NA, Weiner RM, Hutcheson SW. 2003 - Detection and characterization of chitinases and other chitin-modifying enzymes. Journal of Industrial Microbiology and Biotechnology 30, 627-635.

Hyde KD, Jones EBG. 1998 - Marine mangrove fungi. Marine Ecology 9, 15-33.

Hyde KD, Lee SY. 1998 - Ecology of mangrove fungi and their role in nutrient cycling: What gaps occur in our knowledge? Hydrobiologia 295, 107-118.

Hyde KD, Soytong K. 2008 - The fungal endophyte dilemma. Fungal Diversity 33, 163-173.

Kumaresan V, Suryanarayanan TS. 2001 - Occurrence and distribution of endophytic fungi in a mangrove community. Mycological Research 105, 1388-1391.

Kumaresan V, Suryanarayanan TS. 2002 - Endophyte assemblages in young, mature and senescent leaves of Rhizophora apiculata: evidence for the role of endophytes in mangrove litter degradation. Fungal Diversity 9, 81-91.

Li AN, Yu K, Liu HQ, Zhang J et al. 2010 - Two novel thermostable chitinase genes from thermophilic fungi: cloning, expression and characterization. Bioresource Technology 101, $5546-5551$.

Malathi N, Govinda Rajulu MB, Gillet D, Suryanarayanan TS, Moerschbacher BM. 2015 - A high diversity in chitinolytic and chitosanolytic species and enzymes as well as their oligomeric products exist in soil with a history of chitin and chitosan exposure. Biomed Research International 2015, Article ID 857639.

Mandalari G, Bisignano G, Curto RL, Waldron KW, Faulds CB. 2008 - Production of feruloyl esterases and xylanases by Talaromyces stipitatus and Humicola grisea var. thermoidea on industrial food processing by-products. Bioresource Technology 99, 5130-5133.

Muzzarelli RA. 1999 - Native, industrial and fossil chitins. In Jolles P, Muzzarelli RAA (eds.). Chitin and chitinases. Birkhauser Verlag, Basel, 1-6.

Nam T, Park S, Lee SY, Park K et al. 2010 - Tumor targeting chitosan nanoparticles for dualmodality optical/MR cancer imaging Bioconjugate Chem 21, 578-582.

Seidl V. 2008 - Chitinases of filamentous fungi: a large group of diverse proteins with multiple physiological functions. Fungal Biology Reviews 22, 36-42.

Suryanarayanan TS, Kumaresan V, Johnson JA. 1998 - Foliar fungal endophytes from two species of the mangrove Rhizophora. Canadian Journal of Microbiology 44, 1003-1006.

Tamura K, Nei M. 1993 - Estimation of the number of nucleotide substitutions in the control region of mitochondrial DNA in humans and chimpanzees. Molecular Biology and Evolution 10, 512-526.

Tamura K, Peterson D, Peterson N, Stecher G et al. 2011 - MEGA5: Molecular Evolutionary Genetics Analysis using maximum likelihood, evolutionary distance, and maximum parsimony methods. Molecular Biology and Evolution 28, 2731-2739.

Thirunavukkarasu N, Suryanarayanan TS, Rajamani T, Govinda Rajulu MB. 2017 -Diversity and technological potential of fungi from solar salterns of southern India. Kavaka 48, 26-32. 
Thompson JD, Higgins DG, Gibson TJ. 1994 - CLUSTAL W: improving the sensitivity of progressive multiple sequence alignment through sequence weighting, position-specific gap penalties and weight matrix choice. Nucleic Acids Research 22, 4673-4680.

Venkatachalam A, Govinda Rajulu MB, Thirunavukkarasu N, Suryanarayanan TS. 2015 Endophytic fungi of marine algae and seagrasses: a novel source of chitin modifying enzymes. Mycosphere 6, 345-355.

Wang J, Meng Y, Li B, Ma X et al. 2015 - Physiological and proteomic analyses of salt stress response in the halophyte Halogeton glomeratus. Plant, Cell and Environment 38, 655-669.

White TJ, Bruns T, Lee S, Taylor JW. 1990 - Amplification and direct sequencing of fungal ribosomal RNA genes for phylogenetics. In Innis MA, Gelfand DH, Sninsky JJ, White TJ (eds.). PCR protocols: a guide to methods and applications. Academic Press, New York, 315322.

Wirth SJ, Wolf GA. 1990 - Dye-labelled substrates for the assay and detection of chitinase and lysozyme activity. Journal of Microbiological Methods 12, 197-205.

Zhu XF, Tan HQ, Zhu C, Liao L et al. 2012 - Cloning and overexpression of a new chitosanase gene from Penicillium sp. D-1. AMB Express 2, 13. 